\title{
The Sufi Mystical Idiom in Alevi Aşık Poetry: Flexibility, Adaptation and Meaning
}

\section{Caroline Tee}

\section{(Q) OpenEdition Journals}

Electronic version

URL: http://journals.openedition.org/ejts/4683

DOI: $10.4000 /$ ejts.4683

ISSN: $1773-0546$

\section{Publisher}

EJTS

\section{Electronic reference}

Caroline Tee, «The Sufi Mystical Idiom in Alevi Aşık Poetry: Flexibility, Adaptation and Meaning », European Journal of Turkish Studies [Online], Complete List, Online since 29 January 2013, connection on 19 February 2020. URL : http://journals.openedition.org/ejts/4683 ; DOI : 10.4000/ejts.4683

This text was automatically generated on 19 February 2020.

(c) Some rights reserved / Creative Commons license 


\title{
The Sufi Mystical Idiom in Alevi Aşık Poetry: Flexibility, Adaptation and Meaning
}

\author{
Caroline Tee
}

\section{Introduction}

1 The religious tradition of the Alevis in Turkey is characterized in large part by mysticism. Definitions vary, but the broad understanding of mysticism is that it denotes an interest in the experiential knowledge of God rather than, or in addition to, adherence to text-based religious law. In the Alevi case, the mystical pursuit is complex. Whilst it is strongly influenced by the precepts of classical Sufi thought, as well as elements of Sufi ritual practice, Alevilik also draws on the theological motifs and concerns of other religious and cultural traditions, namely, Shi'a Islam and preIslamic Turkic shamanism. These influences complicate Alevi cosmology and approaches therein to mystical encounter with God.

2 There is no clear codification of Alevi mystical religious belief in the form of a written text or creed. Alevilik existed in Anatolia for centuries as a predominately oral tradition, and religious knowledge was transmitted from one generation of Alevi leaders (known as dedes) to the next through the singing of didactic oral poetry. ${ }^{1}$ This ritual poetry addresses the following themes: adulation of Ali and the Twelve Imams of Shi'ism (Düvazimam); mourning for the martyrs of the Battle of Karbala (Mersiye); and the retelling of the Alevi interpretation of the Islamic Miraj story (Miraçlama). Such poetry forms the backbone of the central Alevi religious ritual, the cem ceremony. Whilst the Alevis do not generally reject the written word of the Qur'an, they have not traditionally emphasized it in their religious life; indeed, the centrality and sanctity of sung poetry within the tradition is demonstrated by the euphemistic term 'telli Kuran' (stringed Qur'an), used reverentially to refer to the saz (Turkish lute), which accompanies the performance of poetry in the cem. 
The role of poetry in Alevi society extends beyond the 'sacred' space of the cem. Singerpoets known as aşıks (lit. 'lovers' of God) also perform a crucial function in day-to-day Alevi life. The aşı serves as a kind of voice of his (or, occasionally, her) community, and the poetry may address themes ranging from mystical and profane love to appreciation of the natural world, physical and economic hardship and suffering, and socio-political comment, often tending towards rebellion and dissent. The poetry spans sacred and profane themes without necessarily drawing boundaries between them (Dressler 2003).

4 Much of the language of Alevi aşık poetry is familiar from the classical Persian Sufi verse of poets such as Hafiz, Sa'di and Rumi. It is in this common poetic idiom that the Sufi foundations of Alevilik are perhaps most clearly evident. Yet whilst Alevi poetic language and concerns are familiar from the Sufi canon, the meanings that lie behind that language are, significantly, often quite divergent from mainstream Sufism and are particular to the Alevi context. The language of Persian mystical poetry articulates a complex theology based on the Qur'anic revelation as its major source. In the Alevi case, the language is often used more flexibly and carries different associations that, in turn, reflect the distinctive characteristics of the Alevi mystical worldview.

5 In this article, I explore that worldview through an ethnographic study of the poetry and life experience of a contemporary Alevi aşık called Ozan Seyfili. ${ }^{2}$ I begin by analyzing one of Seyfili's major early poems, called Yolcuyum Yolumda (I Am A Traveller On My Way) in light of the Persian Sufi influence on it. I then move on to discuss other examples of Seyfili's work, in which his usage of the Sufi idiom appears to diverge from the Persian comparison, and contain meanings and referents that are specifically Alevi. I conclude by discussing the status of the community in the Alevi mystical pursuit, which I suggest is distinctive and somewhat elevated.

\section{Ozan Seyfili}

6 Seyfili is the pen-name of Hüseyin Yorulmaz, who was born in the 1940s in the province of Erzincan, central-eastern Anatolia. He has been composing and singing poetry to his own saz accompaniment all his life. Seyfili is a member of an extended family of dedes called the Derviş Cemal Ocak, and as such, he is qualified by birth to potentially lead his Alevi community (Tee 2010). He was apprenticed in his youth in rural Erzincan in the art of leading a cem ceremony, and in performing the ritual poetry therein. ${ }^{3}$ Outside the ritual space his poetic mentor, a rural aşık also from Erzincan called Beyhani, shaped his early development as an aşı. The influence of Beyhani's traditional, rural mysticism is very evident in Seyfili's early poetry.

7 In the early 1960s, like many of his fellow Alevis, Seyfili left the village of his birth and migrated first to Istanbul and then to West Germany. He remained there as a migrant laborer until the early 1980s, whereupon he returned to Turkey and settled on the outskirts of Antalya, where he lives today. Throughout the late 1960s and the 1970s, Seyfili was heavily involved in the socialist movement that attracted many in the Alevi community at the time. His involvement in Alevi religious practice ground to a halt, and he became instead intensely politically active. As such, much of his poetry of that era reflects a Marxist political agenda. Since the so-called 'Alevi revival' of the late 1980s, Seyfili has consciously returned to Alevilik and has been involved since that time in renascent Alevi religious activity amongst the urban Alevi diaspora in the west of 
Turkey. Much of his recent poetry is concerned with Alevi identity and heritage, topics that are very pertinent within the contemporary movement.

The total corpus of Seyfili's poetry spans more than half a century, and incorporates poems addressing the broad range of themes that is typical of its genre (Silay 1998). With the exception of some of the extremely politicized poetry of the 1970s, the Sufi idiom is prevalent throughout, both in poetry that addresses religious topics directly as well as that which does not. Many of the early poems, which Seyfili wrote under the guidance of Aşık Beyhani as a young man in rural Erzincan, are particularly religious in character, and might be described as traditional, Sufi-inspired love sonnets. In his later work, Seyfili's use of the Sufi idiom becomes more flexible, and serves firstly as a broad vocabulary of suffering, often in reference to the historic persecution suffered by the Alevi community, ${ }^{4}$ and secondly as a metaphor of lament for the fragmentation of the Alevi community during the early migratory era. Here, the Sufi idiom - usually reserved for describing the quest of man for relationship with God - is used to describe the Alevi community itself, and Seyfili's nostalgia for the lost human relationships and shared religious ritual that had been the cornerstone of traditional, rural Alevilik.

Seyfili's use of the Sufi poetic idiom in this way reflects a major definitive aspect of Alevi mysticism: the primacy of the community of believers in the mystical quest (Gökalp 1980). Whilst the religious community generally plays an important part in most mystical traditions - Islamic as well as non-Islamic - in Alevilik, its status is greatly elevated. The theological framework for this elevation is provided by the mythological prototype of the cem ceremony, the so-called Kirklarin Cemi or 'Cem of the Forty' (Yaman 1998). The 'Cem of the Forty' is the Alevi interpretation of the Islamic Miraj story, and its primary significance lies is its designation of Ali as the possessor of the secret knowledge of God - knowledge which, in the story, even the Prophet Muhammad himself is not privy to. The other important aspect of the story is the unity of the Forty, who are proto-Alevi believers: when one of them (Ali himself) is cut with a sword, all of them bleed simultaneously and even the blood of Selman, the only one who is not present, drips from the ceiling in solidarity with the group. They declare that, 'birimiz kırkımız, kırkımız birimiz' ('we are one and we are forty, we are forty and we are one'). The cem ritual is intended to replicate this 'Cem of the Forty', and the primary mystical experience that is sought is a return to the spiritual unity of the Forty. This pursuit differs from that of the urban Sufi mystic, whose experience - whilst being rooted in his community, or brotherhood - ultimately seeks to transcend both the material world and his own self, and leave it behind as he is annihilated in (Arabic: fana), or united with God (Netton 2000).

The philosophical and theological framework of the 'Cem of the Forty' is a necessary backdrop to understanding the weighty emphasis on the human community in Alevi thought. It helps to explain the preoccupation in Alevilik with the primacy of 'insanllk' (humanity, or the human being), and its tendency towards humanism and a pantheistic understanding of God and nature. ${ }^{5}$ In the selection of Ozan Seyfili's poems that follows, I explore the way in which his use of the Sufi poetic idiom is subtly transformed in a way that reflects the humanist emphasis and particularities of Alevi mystical thought.

11 Chronologically the first poem that Seyfili composed, which reflects the early influence of Aşık Beyhani and the rural mysticism of the pre-migratory era, is called Yolcuyum Yolumda (I Am A Traveller on My Way). ${ }^{6}$ It typifies the religious tenor of much of 
Seyfili's early work, and represents a fairly conservative and traditional usage of the Sufi poetic idiom:

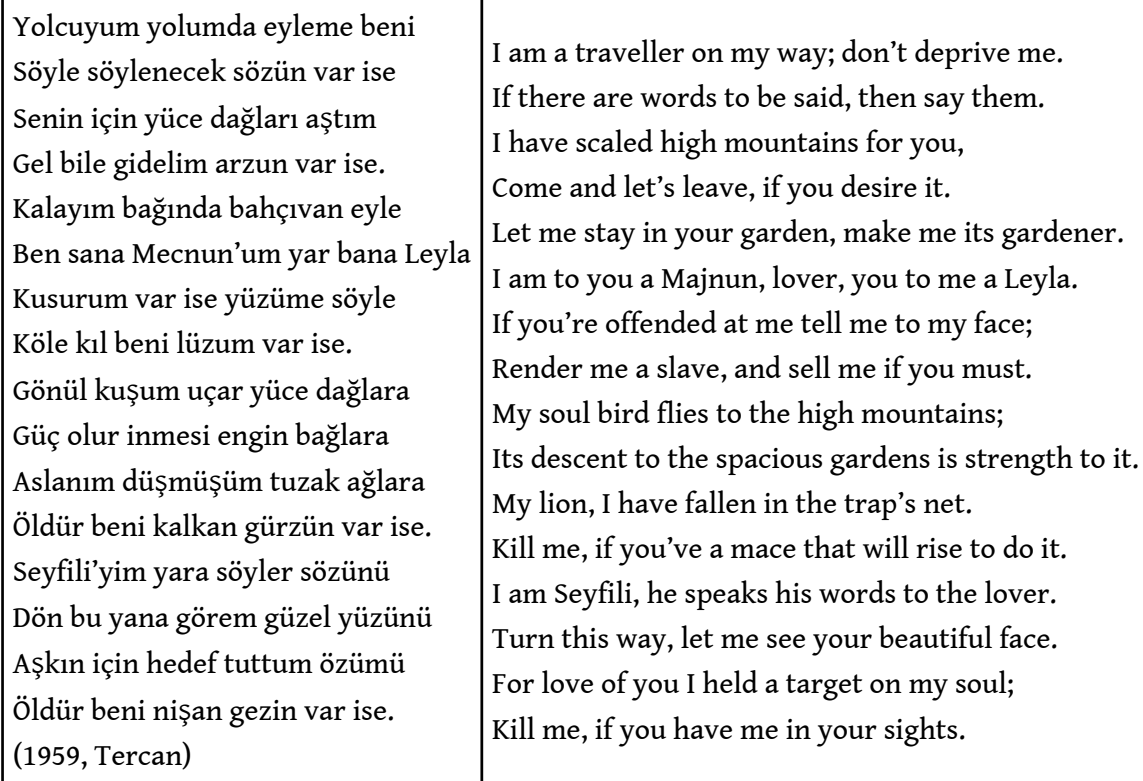

There are numerous instances in this poem of the language and theological motifs of Sufism, and it lends itself to a direct comparison with the Persian Sufi canon. The desire for unification with the addressee, whom we infer to be God, pervades the poem. As such, it follows the well-established literary precedent of 'The Song of the Reed' with which Rumi begins his epic Mathnawi. In the Song, the reed flute (an instrument frequently used in the Sufi semah and especially by Rumi's Mevlevi Order) mourns its separation from the pre-eternal reedbed, as a metaphor for the separation of the human soul from God, who is its source (Mojaddedi 2004: 4).

Besides the broad articulation in Yolcuyum of this Sufic notion of separation and longing for reunion (Arabic: shawk), there are also specific instances throughout the poem of Seyfili's use of particular Persian Sufi poetic concepts: in the title itself, the poet's self-referential status as a traveller is typical of many Persian poets, who often use the metaphor of travel or wandering to express the movement of the restless, individual soul; in verse two, Seyfili mentions a garden and his own role as its gardener, both of which are familiar images in Sufi poetry. The garden of the soul is the metaphorical arena in which the Sufi (as the gardener) cultivates his mystical love, and it is also where the ubiquitous Sufi poetic motif of the nightingale and the rose belong.

The reference to Majnun and Leyla in verse two, line two - which is the first of many such references in the wider body of Seyfili's work - alludes to the romantic lovers of Nizami Ganjavi's (d. c. 1209) famous poem Layli va Majnun (Gelpke 1997; Seyed-Gohrab 2003). Right across the Islamic world, Majnun (which means 'madman') is a popular symbol of the wild lover who loses his mind through years of desperate wandering in the desert in pursuit of Leyla, his earthly beloved. In the Sufi reading of the poem, Leyla the girl is transformed into the Divine Beloved who is the real goal of Majnun's pursuit, and it is his un-realizable longing for union with God which drives him insane until the eventual attainment of that union through his death at the end of the poem. 

him permission to sell him as such. The slave relationship with God is well understood in Islam generally, and is a notion substantiated by the Qur'anic text itself. In Sufi thought, the slave relationship between the individual believer and God is particularly important, and moreover it is a slavery that the individual embraces and to which he willingly submits. Nizami's Majnun, for example, makes the following declaration at that stage in the story when his father takes him to be 'cured' of his love-madness by praying at the ka'ba in Mecca (Dastgirdi 1378: 335):

In the circle of love I sell my soul; let my ear never be without her earring. ${ }^{8}$

The earring that he refers to is that traditionally worn by a slave to denote his or her status, and is a metaphor for his complete submission to the rule of God - as love - over him. Seyfili's use of the same metaphor in verse two, line four, and the submission of the poetic voice to the status of love's slave, is resonant with the same mystical Islamic overtones.

Verse three of Yolcuyum begins with a reference to the 'soul bird', another Sufi poetic motif for which the precedent was set by Farid al-Din Attar in his epic poem, Conference of the Birds (Darbandi and Davis 1984; Ritter 2003). ${ }^{9}$ The 'soul bird' can take a variety of different forms, the most ideal being the nightingale, which is infatuated with the rose, representing the beauty of God. Seyfili's 'soul bird' flies to the high mountains, which represent the troubles of the world and the obstacles which must be overcome in order to attain the longed for union with God, and then descends to 'spacious gardens', a descent from which it gains strength because it is there that the love relationship with God can be cultivated.

The third line of verse three talks of the 'trap's net', into which the poet has fallen, an image whose juxtaposition with the 'soul bird' motif is common in Sufi poetry. This juxtaposition has foundations in Sufi theology, and Annemarie Schimmel finds one of many exemplary precedents for it in Rumi's Divan (Schimmel 1982: 112):

Love appears often as a trap or a net for the soul bird. What bird could or would flee from the grains, sugar, and almonds which are its bait? Indeed:

He who is far away from the net of love

Is a bird that does not have a wing!

[...] The paradox of Love is that man becomes the freer the more he is captured by

it, for only thanks to Love will he be able to fly heavenward. ${ }^{10}$

Being captured by the 'net of love' ultimately spells death to the mystic 'soul bird', which is a poetic metaphor for the theological doctrine of annihilation (fana). This is the final goal of the Sufi mystic, and is to be desired not only for the sake of union with God in itself but also to bring an end to the intense suffering experienced in separation. Thus the trap of the net is one that is paradoxically deliberately sought after by the metaphorical soul bird, and into whose clutches it desires to fall.

Accordingly in Seyfili's poem, in the line following the image of the net (verse three, line four) the poet implores the lover to kill him, an imperative that is repeated in the final couplet of the poem. Death at the hands of the lover (in Persian, kushta-yi ma'shuq) is a fate welcomed by many Sufi poets, because of the ensuing title of martyr and guarantee of eternal life which are thought to be thus secured. ${ }^{11}$ An interesting comparison with Seyfili's closing couplet in Yolcuyum can be made with one of the foundational texts in Persian Sufism, Ahmad Ghazali's Sawanih (Seyed-Gohrab 2003: 127): 
Draw an arrow in my name from your quiver

And place it on your drawn bow;

If you seek a target, take my heart:

A mighty shot from you and a joyous sigh from me. ${ }^{12}$ practice has been undergoing a process of reformulation (Massicard 2005). This publicly reformulated manifestation of Alevilik is distinct in many ways from what might be termed its 'traditional' incarnation. One of the major features of Alevilik that has been emphasized in the revival is its apparently pacifistic nature. This is evidenced by Seyfili's poem Katlandık (We Endured), which he wrote in response to the notorious ' mum söndu' allegations..$^{13} \mathrm{He}$ explains:

Katlandik is about not becoming like the oppressor. I wrote it on behalf of all the Kızılbaş Alevis when the Sunnis were slandering us with mum söndü allegations. My intention was to explain to the Sunnis what we Alevis believe. Each person should carry out his own worship and not worry about the others.

verb 'katlanmak' means to tolerate or to endure, and it is used in the poetic refrain at the end of each verse. It is a noticeably reconciliatory poem, which contains no suggestion of ill-will in response to the slanderous allegations but rather emphasizes the notion - popular since the revival - that Alevilik is a tradition of peace. There are Sufi motifs scattered throughout the poem, primarily in verse one, line one: 'we waited in hope for the beautiful lover'; verse two, line two: 'my flame has not gone out, my fire burns'; and verse three, line three: 'turning the poison into honey, we mixed it with the wine'. However, the closing verse confirms that the subject of the poem is not primarily a mystical one, but rather a plea for tolerance of the Alevis as a religious community:

\begin{tabular}{|l|l|}
\hline Seyfili duyulsun figanım zarım & Seyfili, let it be heard, my lament, my anguish \\
Sevgidir barıştır dostluk ısrarım & My insistence is on love, peace and friendship \\
Çok bühtanlar sürdü bizlere zalim & The oppressor has slandered us greatly \\
Pes eyledik acılara katlandık. & We yielded, we endured the pain. \\
\hline
\end{tabular}

The Sufi motifs are, then, used in this poem to different effect than in the earlier work. The 'beautiful lover' who is referred to in the first line does not appear to be a reference to God, or even to a human beloved disguised by the language of mysticism, but rather to a generic notion of peace, tolerance and friendship. 
Verse three uses the language of mysticism to allude to the centrality of human reconciliation and peace-making to the cem ceremony:

'Hü!' deyip cemlerde çerağı yaktık Saying 'Hü!' in the cems, we lit the candle

$\begin{array}{lll}\text { Zehiri bal edip badeye kattı. } & \text { Turning the poison to honey, we mixed it with wine. }\end{array}$

27 Katlandık illustrates one of the founding principles of Alevi ritual, which is the restoration and restitution of broken human relationships. ${ }^{14}$ The Sufi motifs of honey and wine are used here to express this principle, but their meaning has clearly departed quite considerably from the one implied by the Persian poets.

Gardas (Brother) ${ }^{15}$ is a poem that was written in the 1970s, a decade characterized by serious civil unrest in Turkey and marked by a military coup at its beginning and end. Seyfili often speaks of '12 Mart' (12 March) and '12 Eylül' (12 September), references to the coups on those dates in 1971 and 1980 which he uses as a kind of idiom for that overall period of strife and oppression experienced by the Alevis then, for their participation in the activities of the political left.

Gardaş articulates the difficulties of being an aşık during that time, and the repercussions that Seyfili faced at the hands of the authorities for speaking out (as it is incumbent on the aşık to do) against the injustice that he perceived was being perpetrated around him. As were many engaged in political activity during that period, he was arrested and imprisoned on various occasions. The first and penultimate stanzas of Gardaş are given here:

\begin{tabular}{|l|l|}
\hline Engeller önümde, baskı başımda & Obstacles before me, intimidation from above, \\
Ozan olmak, aydın olmak zor gardaş & Being an ozan's hard, brother; being enlightened is hard. \\
Savcılık, adliye, polis peşimde & The prosecutors, the courts, the police are after me \\
Ozan olmak, şair olmak zor gardaş. & It's hard to be an ozan, brother, hard to be a poet. \\
Bülbül ahraz olmuş karga önünde & The nightingale's gone silent, there's a crow before him \\
Kuzgunlar şahinler karga yanında & And ravens and hawks beside it. \\
Cehalet vurur o an damarına & Ignorance strikes him at that moment, in his vein \\
Ozan olmak, şair olmak zor gardaş. & It's hard to be an ozan, brother, hard to be a poet. \\
\hline
\end{tabular}

30 What is interesting about this poem is Seyfili's use of the mystical nightingale metaphor to talk of political oppression and socio-religious discrimination. The nightingale is no longer located in its traditional role, singing a mournful cry as it seeks the beauty of the rose. Rather, it is defined here by its very silence, and as such appears to have become representative of a new concern which, following on from the references to the 'prosecutors', 'courts', and 'police' is suggestive of the socio-political strife of the time, rather than having any association with its more traditional, mystical aspirations.

31 Another poem that contains much of the imagery and language of the Sufi genre, but behind which is an autobiographically inspired sub-text of Alevi suffering and persecution, is Yüksek Uçma (Don't Fly High). Seyfili wrote this poem in 1963, and explains the story behind its composition in the following words:

When I was a young man, there were fifty pairs of cranes which would come to our village every year. Cranes are monogamous so they would come in pairs. They were 
beautiful, and I am fortunate to have seen them. They would turn the semah over the water of the Euphrates. One day a soldier shot one of the cranes dead with his rifle. We protested to the ağa. Two weeks afterwards, the soldier was hit by a train and he died. The dead crane's partner returned every year with its young, but it never took another partner. When I returned to the village recently, there were only seven pairs of cranes there. The natural environment has changed and so they no longer come.

The poem is ostensibly an entreaty to the crane not to fly, that it might escape being hit by the soldier's bullet, but there are various different layers of meaning and metaphorical representation involved:

\begin{tabular}{|l|l|}
\hline Yüksek uçma telli turnam & Don't fly high, my wiry crane \\
Yorulursun, yorulursun & You'll grow weary, you'll grow weary. \\
Bu sevdanın gözü kördür & The eye of this passion is blind \\
Vurulursun, vurulursun. & You will be hit, you will be hit. \\
Bir ricam var gülüm sana & I have a request of you, my rose \\
N'olur uğra Erzincan'a & Please, stop by Erzincan. \\
Yardan haber getir bana & Bring me news from my lover \\
Ne olursun, ne olursun. & I implore you, I implore you. \\
Bana gücenme gel canım & Don't be mad at me, come, my dear \\
Ovalar senin mekanın & The plains are your home. \\
Yüksek uçma, tek israrım & Don't fly high, it's my one insistence \\
Yorulursun, yorulursun. & You'll grow weary, you'll grow weary. \\
Özlem çekersin yarına & You will yearn for tomorrow \\
Benzersin dertli birine & You'll be like a troubled one. \\
Benim gibi kaderine & Like me, you'll scold your fate \\
Darılırsın, darılırsın. & You'll scold your fate. \\
İçim burkuluyor dertten & My soul is twisted in affliction \\
Yandım kavruldum hasretten & I have burned, I have been scorched by longing. \\
Seyfili gibi gurbetten & Like Seyfili, you will be wiped on the floor \\
Sürünürsün, sürünürsün. & In a place far from home. \\
\hline
\end{tabular}

The 'rose' and the 'lover' of verse two, the 'yearning' and the mention of fate in verse four, and the 'burning' and 'scorching by longing' in verse five are all extremely reminiscent of the mystical motifs of the Persian poets, and lend the poem a powerful atmosphere of tragedy and suffering familiar from the Sufi material. Yet it has a subtext that is very specific to the Alevi case, which is particularly evident in Seyfili's use of the crane as its central subject.

The crane is a popular motif in Turkish folk poetry generally, but carries special significance to the Alevis, who, like Seyfili in his story, compare its airborne turning to the movement of the semah. ${ }^{16}$ It is commonly referred to as the 'telli turna' (wiry crane), an appellation that carries associations of sanctity on account of its proximity to the term 'telli Kuran' ('the stringed Qur'an', Alevi euphemism for the saz), and this sacred association is further emphasized by the Alevis through their likening of its cry to the voice of Ali. The mention made of the monogamous nature of the crane in the story belies Seyfili's reverence for it - and identification with it - because the Alevis generally pride themselves on practicing monogamous marriages, and are often critical of the polygamy sanctioned by other schools of Islam. ${ }^{17}$ 

for in the broad field of Islamic literature the preservation of tradition is firmly prioritized over the quest for originality of expression. As such, it befalls Seyfili to make use of an established range of symbolism and imagery rather than fashion his 
own, and he can safely assume that his readers/listeners will not find it unusual, surprising or even disappointing that he does so.

Natalie Moyle reaches the same conclusion in her study of the hikaye tradition amongst the aşıks of the northeastern Anatolian town of Kars, where she observes that, 'consistent with Islamic aesthetics, certain images are (indeed) used repeatedly', but that this does not appear to compromise the artistic integrity of the poetry in any way (Moyle 1990: 135). ${ }^{22}$ Annemarie Schimmel makes the following observation of Islamic folk poetry more generally, and its similarity to the high poetry in this regard (Schimmel 1982: 142):

The folk poets followed the Koranic injunction to find God's signs "in the earth and in yourselves - do you not see?" (Sura 51/21). In their poetry age-old symbols came to life again. Yet, in the history of mystical folk poetry too the process of repetition and fossilization of forms, topics and images is as visible as in high poetry.

In Dostlar Hey, then, as in much of his poetry, Seyfili appears to be acting very much within the parameters of the mystical Islamic folk tradition, by taking those 'age-old symbols' and continuing to use them as poetic metaphors even when they have digressed from their original religious meanings.

\section{Sufi Imagery in the Period of Alevilik's Fragmentation}

Seyfili's tendency to use the language of Sufi mysticism when talking of the Alevi community can be seen particularly clearly in the poetry written around 1960, during his early years away from his homeland of Erzincan when he was a migrant worker in Istanbul. These poems express his sadness at the disintegration of the social and ritual institutions of rural Alevilik in the new urban setting.

The Alevi tradition indeed suffered a great rupture during the early period of mass rural to urban migration in the 1960 s and 70 s, for historically extremely close-knit Alevi village communities found no recourse to practice their traditions in the anonymous big cities of the Turkish west. With the loss of the closed social structure of the village, the crucial relationships between individuals ${ }^{23}$ as well as between dede and follower were severely weakened. Seyfili recalls his experience of that era in the following words:

When I first went to Istanbul, I was only a youth. I worked on a construction site in the summers when there was lots of work. I remember on Fridays, all the Sunni workers would go to do their prayers at the mosque at midday, but I had nowhere to go. We didn't have anywhere to meet, anywhere to practice our cem. There was no togetherness, no community.

Two poems that express Seyfili's loneliness during this period, and his sadness at the disintegration of Alevilik, are Yozlaştı (Degenerated) and Ayıkmıyor Başım (I Can't Clear My Head). Both poems draw on the language as well as certain broad theological themes of Sufi poetry. The opening lines of Yozlaştı are resonant with mystical metaphors:

\begin{tabular}{|l|l|}
\hline Aşıllar sevdasız aşklar duygusuz & Aşıks without passion, love without feeling \\
Mecnun'un sahrası, çöle yozlaştı & Majnun's desert, his plain has degenerated. \\
Bülbülün feryadı dillere destan & The legendary cry of the nightingale, \\
Bahçıvanı gafil, gülü yozlaştı. & The gardener's been careless, the rose has degenerated.
\end{tabular}


The Sufi image of the careless gardener who has failed to cultivate the rose is used here as a metaphor for the disintegration of Alevilik in the big city. In later verses of the same poem, Seyfili mourns the fact that 'the seas have been dirtied and the lake debased', and 'the honey in the beehive has degenerated', drawing again on the stock imagery of Persian Sufi poetry to express his sense of loss over the fragmentation of the Alevi community.

\section{The Sufi Idiom Describing the Alevi Community Rather than God}

Seyfili's use of the Sufi imagery in this context differs from its usage in the comparatively straightforward, religious love poem, Yolcuyum Yolunda. In that poem, Seyfili's poetic voice is situated very much within the tradition according to whose poetic norms it speaks. In Yozlaştı, however, he has taken a step back from that tradition and begun to use its stock imagery and metaphor to express something different: the idiom of Sufi mysticism is used here to describe the Alevi community itself, rather than the personal relationship between the poet and God, or the 'lover', as it does in the classical Persian context.

This appropriation of Sufi poetic imagery, the language of love-mysticism, to express the demise of his religious community (rather than the unattainability of God) points to the greatly elevated status of the Alevi community and its function in Seyfili's religious experience. Without the community, there can be no such experience, and the loss of that community is mourned with the same strength of feeling - indeed, the same poetic idiom - as the classical Persian poets lament their separation from God.

This notion of separation is also powerfully expressed in Ayıkmıyor Başım. This poem laments the fragmentation of the Alevi community in a rather more straightforward idiom, but has at its heart the same powerful motif of separation that is so reminiscent of the Persian material:

\begin{tabular}{|l|l|}
\hline Rıza ile lokma yenilmez oldu & The lokma could no longer be eaten with consent \\
Kırkların Cemine gidilmez oldu & The Cem of the Forty could not be held \\
Gülbenkler çekilip verilmez oldu & Prayers could not be read, could not be given \\
Talip ayrı düştü, pir ayrı düştü & The disciple and the pir have parted \\
Haydar Haydar Haydar, pir ayrı düştü. & Haydar Haydar Haydar, the pir has parted. \\
\hline
\end{tabular}

51 The compound verb used in the refrain, and which occurs a total of ten times in the poem as a whole, is ayrı düşmek, meaning 'to become separated', the circumstance which is being so strongly lamented in the poem. The lokma is a reference to shared food, used primarily in the ritual context of the cem to denote the communal meal of sacrificed meat at the end, but also used more broadly in reference to food given and shared amongst the Alevi community. The eating of lokma in the cem can only take place when everyone in the community has declared rizalik (approval, or consent) with one another; that is, when there is peace established within the community. It is the loss of this experience that Seyfili is lamenting here, for in the anonymity of Istanbul in 1959 Alevi migrants such as he became isolated from their communities, cem ceremonies could not be held, and rizallk could therefore not be established. Seyfili 
explained to me the enormous spiritual significance of rizalik within the community to the Alevis:

C. Tee: How does an Alevi find forgiveness for his sins? Does God forgive them?

Seyfili: Only the people can be satisfied [razi] in the cem. Whether or not God has forgiven you is a secret. Neither the dede nor anyone else can interfere with this. There is a saying, 'only God knows the heart'. God knows the secrets, and nobody has the right to say they forgive you in God's name. We do not interfere with God's work [Allah'in işine karışmayız, biz].

The authority of the community, and the importance of good inter-communal relations, is therefore paramount, and so separation from it should consequently be understood to be extremely grave. Its implications far exceed the anticipated realm of loneliness and socio-cultural isolation, and extend to the heart of Seyfili's religious and spiritual experience as an Alevi. He uses the Sufi idiom of spiritual separation from God to articulate his separation from the Alevi community because it is there, in the human community, that he has access to rizallk, or forgiveness.

\section{Conclusion}

53 The use of the language of Sufism in Seyfili's poetry reveals one of the distinctive features of Alevi mysticism, which is the greatly elevated status of the human community therein. This mystical cosmology and worldview was developed over centuries in often isolated and always introverted Alevi communities in rural Anatolia, where the unity and integrity of the community was paramount. Indeed, in the face of Ottoman Sunni hostility, it was a key to the survival and propagation of the tradition. ${ }^{24}$ In the present day, the situation is very different and most Alevis now live in the demographically mixed and relatively anonymous urban centres in the west of Turkey and Western Europe.

The so-called modern Alevi movement, which began in the late 1980s, has seen a reawakened interest in Alevi identity in this new environment and, in many cases, a return to ritual practices such as the cem. These contemporary cem ceremonies - held in new, purpose-built urban cemevis - are, however, quite different from their rural prototype: rather than being intimate and highly secretive, they are large in scale and often open to outsiders. The desire for official recognition by the Turkish state and engagement in identity politics has meant that, in many cases, the cem has arguably lost some of its 'mystical' function and become a public symbol and even a defense of Alevilik to the outside world.

It is unclear what will become of Alevi mysticism in this modern, reformulated Alevilik. Altered demographic distribution, together with the processes of codification and institutionalization, has had a profound and inevitable effect on the mystical significance of the community. It should, however, be expected that Alevi aşıks such as Ozan Seyfili will continue to use the language of mysticism flexibly and adaptively in their poetry, even as they articulate the myriad new challenges - be they religious, social, legal or political - faced by the Alevis in the $21^{\text {st }}$ century. 


\section{BIBLIOGRAPHY}

Avery, Peter and Heath-Stubbs, John (tr.) (1952) Hafiz of Shiraz: Thirty Poems, London, John Murray.

Birge, John Kingsley (1994) The Bektashi Order of Dervishes, London, Luzac Oriental.

Darbandi, Afkham and Davis, Dick (tr. and eds.) (1984) The Conference of the Birds/Farid ud-Din Attar, Harmondsworth, Penguin.

Dastgirdi, Vahid (ed.) (1378) Hakim Nizami Ganjavi, Tehran.

Dressler, Markus (2003) 'Turkish Alevi Poetry in the Twentieth Century: The Fusion of Political and Religious Identities', in Alif: Journal of Comparative Poetics, No.23, Literature and the Sacred, pp. 109-154.

Ernst, Carl W (1999) 'The Stages of Love in Early Persian Sufism, from Rabi'a to Ruzbihan', in The Heritage of Sufism Vol. 1, ed. L. Lewisohn, Oxford, Oneworld, pp.435-455.

Gelpke, Rudolph (tr. and ed.) (1997) The Story of Layla and Majnun, NY, Omega.

Gökalp, Altan (1980) Tetes Rouges et Bouches Noires: une confrérie tribale de l'Ouest anatolien, Paris, Société Ethnographie.

Imber, Colin H (1979) 'The Persecution of the Ottoman Shi'ites According to the Mühimme Defterleri, 1565-1585', in Der Islam 56, pp.245-273.

Öztelli, Cahit (1973) Bektaşi Gülleri, Alevi-Bektaşi şiirleri Antolojisi, Istanbul, Millet Yayınları.

Markoff, Irene (1991) 'The Ideology of Musical Practice and the Professional Turkish Folk Musician: Tempering the Creative Impulse', in Asian Music, Volume 22 pp.129-145.

Massicard, Élise (2005) L'autre Turquie: le mouvement aléviste et ses territoires, Paris, Presses Universitaires de France.

Mojaddedi, Jawid (tr.) (2004) Rumi: The Mathnawi, Book One, Oxford, Oxford University Press.

Moyle, Natalie Kononenko (1990) The Turkish Minstrel Tale Tradition, New York, Garland.

Netton, Ian Richard (2000) Sufi Ritual: The Parallel Universe, Richmond, Surrey, Curzon.

Pinguet, Catherine (2009) Les alévis, bardes d'Anatolie, Paris, Editions Koutoubia.

Redhouse Ottoman Turkish-English Dictionary (2000) Istanbul, Millet Publishing.

Ritter, Hellmut (tr. John O'Kane) (2003) The Ocean of The Soul: Man, the World and God in the Stories of Farid al-Din Attar, Leiden, Brill.

Schimmel, Annemarie (1982) As Through A Veil: Mystical Poetry in Islam, New York/Guildford, Columbia University Press.

Seyed-Gohrab, A.A. (2003) Layli and Majnun: love, madness and mystical longing in Nizami's epic romance, Leiden, Brill.

Silay, Kemal (ed.) (1998) Turkish Folklore and Oral Literature: Selected Essays of Illhan Başgöz, Bloomington, Indiana, Indiana University Turkish Studies.

Tee, Caroline (2010) 'Holy Lineages, Migration and Reformulation of Alevi Tradition: A Study of the Derviş Cemal Ocak from Erzincan', British Journal of Middle Eastern Studies Vol. 37 (3), pp. 335-392. 
Turabi (Ali Dedebaba): Divan (1294 A.H.) Istanbul, Tophane-i Amire Matbaası.

Yaman, Mehmet (1998) Alevilik'te Cem, Istanbul, Ufuk Matbaası.

- (2007) Alevilik: İnanç, Edeb, Erkan, Istanbul, Ufuk Reklamcılık ve Matbaacılık.

\section{APPENDIXES}

Here follow the full Turkish texts of the poems referred to partially in the article, alongside my own English translations. The Turkish texts are given as Seyfili presented them to me and contain occasional inconsistencies in grammar and spelling that reflect his eastern Turkish dialect.

\begin{tabular}{|c|c|}
\hline$\underline{\text { Katland } k}$ & We Endured \\
\hline $\begin{array}{l}\text { Umutla bekledik güzel yarını } \\
\text { Düş eyledik acılara katlandık } \\
\text { Yaralı gönlü kırık kalpleri } \\
\text { Taş eyledik acılara katlandık. }\end{array}$ & $\begin{array}{l}\text { We waited with hope for the beautiful lover } \\
\text { We dreamt, we endured the pain } \\
\text { With injured souls and broken hearts } \\
\text { We hardened ourselves, we endured the pain. }\end{array}$ \\
\hline $\begin{array}{l}\text { Evveli ne ise dünü bir düşün } \\
\text { Sönmedi alevim yanar ateşim } \\
\text { Yetmiş iki millet birdir kardeşim } \\
\text { Hoş eyledik acılara katlandık. }\end{array}$ & $\begin{array}{l}\text { Whatever was before, think of yesterday } \\
\text { My flame has not gone out, my fire burns } \\
\text { My brother, the } 72 \text { millets }^{25} \text { are one } \\
\text { We were genial, we endured the pain. }\end{array}$ \\
\hline $\begin{array}{l}\text { Ne firsat kolladık ne de kin tuttuk } \\
\text { 'Hü’ deyip cemlerde çerağı yaktık } \\
\text { Zehri bal edip badeye kattık } \\
\text { Nuş eyledik acılara katlandık. }\end{array}$ & $\begin{array}{l}\text { We neither watched for an opportunity nor did we hold a } \\
\text { grudge } \\
\text { Saying } h \ddot{u}^{26} \text { in the cems, we lit the candle } \\
\text { Turning the poison to honey we mixed it with wine } \\
\text { We drank it, we endured the pain. }\end{array}$ \\
\hline $\begin{array}{l}\text { Kem söz çımaz ehl-i kamil } \\
\text { dilinde } \\
\text { Arif olan anlar mazlum halinde } \\
\text { Dara durduk erenlerin yolunda } \\
\text { Cuş eyleyip acılara katlandık. }\end{array}$ & $\begin{array}{l}\text { Evil words are not spoken in the language of ehl-i kamil }{ }^{27} \\
\text { The wise one understands, in his oppressed state } \\
\text { We came to the } d a r^{28} \text { on the road to enlightenment } \\
\text { We were ebullient, we endured the pain. }\end{array}$ \\
\hline $\begin{array}{l}\text { Seyfili duyulsun figanım zarım } \\
\text { Sevgidir barıştır dostluk ısrarım } \\
\text { Çok bühtanlar sürdü bizlere zalim } \\
\text { Pes eyledik acılara katlandık. }\end{array}$ & $\begin{array}{l}\text { Seyfili, let it be heard, my lament, my anguish } \\
\text { My insistence is on love, peace and friendship } \\
\text { The oppressor has slandered us greatly } \\
\text { We yielded, we endured the pain. }\end{array}$ \\
\hline
\end{tabular}

\begin{tabular}{|l|l|}
\hline Gardaș $^{29}$ & Brother \\
\hline $\begin{array}{l}\text { Engeller önümde, baskı başımda } \\
\text { Ozan olmak, aydın olmak zor gardaş } \\
\text { Savcıllk, adliye, polis peşimde } \\
\text { Ozan olmak, şair olmak zor gardaş. }\end{array}$ & $\begin{array}{l}\text { Obstacles before me, intimidation from above, } \\
\text { The prosecutors, the courts, the police are after me } \\
\text { It's hard to be an ozan, brother, hard to be a poet. }\end{array}$ \\
\hline
\end{tabular}




\begin{tabular}{|c|c|}
\hline $\begin{array}{l}\text { Potansiyel suçlu gibi bakılır } \\
\text { Soran yoktur neden yanar yakılır } \\
\text { Perişandır üstü başı dökülür } \\
\text { Ozan olmak, şair olmak zor gardaş. }\end{array}$ & $\begin{array}{l}\text { Potential is looked on as guilt } \\
\text { Nobody asks why he burns, why he's burned } \\
\text { His clothing is ragged, he's all down at heel } \\
\text { It's hard to be an ozan, brother, hard to be a poet. }\end{array}$ \\
\hline $\begin{array}{l}\text { Bağlama elinde türkü dilinde } \\
\text { O gidiyor Pir Sultan'ın yolunda } \\
\text { Ne etseler Ozan memnun halinde } \\
\text { Ozan olmak, şair olmak zor gardaş. }\end{array}$ & $\begin{array}{l}\text { His saz in his hand and a folk song on his tongue, } \\
\text { He's travelling down Pir Sultan's road } \\
\text { Whatever they might do, the ozan's content to be so } \\
\text { It's hard to be an ozan, brother hard to be a poet. }\end{array}$ \\
\hline $\begin{array}{l}\text { Bülbül ahraz olmuş karga önünde } \\
\text { Kuzgunlar şahinler karga yanında } \\
\text { Cehalet vurur o an damarına } \\
\text { Ozan olmak, şair olmak zor gardaş. }\end{array}$ & $\begin{array}{l}\text { The nightingale's gone silent, there's a crow before him } \\
\text { And ravens and hawks beside it. } \\
\text { Ignorance strikes him at that moment, in his vein } \\
\text { It's hard to be an ozan, brother, hard to be a poet. }\end{array}$ \\
\hline $\begin{array}{l}\text { Hepsi söz birliği etmişçesine } \\
\text { Ses veren yok Seyfili'nin sesine } \\
\text { Yobazlar dikilmiş tam ensesine } \\
\text { Ozan olmak, şair olmak zor gardaş. }\end{array}$ & $\begin{array}{l}\text { They say we speak as one voice } \\
\text { But no one speaks out for Seyfili } \\
\text { The fanatics have grabbed him by the scruff of his neck } \\
\text { It's hard to be an ozan, brother, hard to be a poet. }\end{array}$ \\
\hline
\end{tabular}

\begin{tabular}{|c|c|}
\hline Dostlar Hey & Hey Friends \\
\hline $\begin{array}{l}\text { Acılı sancılı dertli kederli } \\
\text { Bugünüm de böyle geçti dostlar } \\
\text { hey. } \\
\text { Derdim yetmez başka dertler } \\
\text { başıma } \\
\text { O vefasız geldi açtı dostlar hey. }\end{array}$ & $\begin{array}{l}\text { Painful, griping, sorrowful, troubled } \\
\text { My today has gone like this, hey friends. } \\
\text { My cares were not enough, still more have come upon me } \\
\text { It came disloyally, causing trouble, hey friends. }\end{array}$ \\
\hline $\begin{array}{l}\text { Açtırma yaramı hiç bakıp görme } \\
\text { Derindedir yaram elini sürme } \\
\text { Acı sancı fazla vallahi sorma } \\
\text { Kader beni bulup seçti dostlar hey. }\end{array}$ & $\begin{array}{l}\text { Don't have my wound opened, don't look and see } \\
\text { My wound is deep, don't touch it } \\
\text { It is painful and griping, by God, don't ask } \\
\text { Fate found me and chose me, hey friends. }\end{array}$ \\
\hline $\begin{array}{l}\text { Herşey güzel gidiyordu yolundan } \\
\text { Çok pintiyim bir şey gelmez } \\
\text { elimden } \\
\text { Belli olur duruşumdan halimden } \\
\text { İz bıraktık gölge geçtik dostlar hey. }\end{array}$ & $\begin{array}{l}\text { Everything was fine, it was all going well } \\
\text { I am so tight-fisted, there's nothing I can do about it } \\
\text { It's obvious from my posture, from my state } \\
\text { We left a mark and passed into the shadow, hey friends. }\end{array}$ \\
\hline $\begin{array}{l}\text { Sevginin kuluyum ben turabiyim } \\
\text { Bir pecmürde kulum ben harabiyim } \\
\text { Aşkım badesiyim ben şarabıyım } \\
\text { Deli gönül kana kana içti dostlar } \\
\text { hey. }\end{array}$ & $\begin{array}{l}\text { I am love's slave, I am turabi }{ }^{30} \\
\text { I am a wretched slave, I am harabi }{ }^{31} \\
\text { I am love's potion, I am its wine } \\
\text { My mad soul drank it bleeding, bleeding, hey friends. }\end{array}$ \\
\hline
\end{tabular}




\begin{tabular}{|c|c|}
\hline $\begin{array}{l}\text { Seyfili kendini böyle yargılar } \\
\text { Sökülmüş yaralar düşmüş sargılar } \\
\text { Bazen ağlar bazen haline güler } \\
\text { Baston elde gençlik uçtu dostlar } \\
\text { hey. }\end{array}$ & $\begin{array}{l}\text { Seyfili judges himself thus } \\
\text { Wounds unstitched and bandages askew } \\
\text { Sometimes he cries, sometimes he laughs at his state } \\
\text { The walking stick in his hand, youth has flown away, hey } \\
\text { friends. }\end{array}$ \\
\hline (1993, Antalya) & \\
\hline
\end{tabular}

\begin{tabular}{|l|l|}
\hline Yozlaștı & Degenerated \\
\hline $\begin{array}{l}\text { Aşıklar sevdasız aşklar duygusuz } \\
\text { Mecnun'un sahrası çölü yozlaştı. } \\
\text { Bülbülün feryadı dillere destan } \\
\text { Bahçıvanı gafil gülü yozlaştı. }\end{array}$ & $\begin{array}{l}\text { Aşıks without passion, love without feeling } \\
\text { Majnun's desert, his plain has degenerated. } \\
\text { The legendary cry of the nightingale, } \\
\text { The gardener's been careless, the rose has degenerated. }\end{array}$ \\
\hline $\begin{array}{l}\text { Ne edep ne erkan nerede ikrar } \\
\text { Beyhude ağlamak ne işe yarar } \\
\text { Her nereye baksan bir tahribat var } \\
\text { Talip pire dargın yolu yozlaştı. }\end{array}$ & $\begin{array}{l}\text { Neither rules nor etiquette, where is the confession } \\
\text { Wherever you look there's destruction } \\
\text { The road from follower to pir is angry and degenerated. }\end{array}$ \\
\hline $\begin{array}{l}\text { Dünyaya bakmayız dar pencereden } \\
\text { Kurtulmak gerekir bu cendereden } \\
\text { Bu mülkün sahibi şahı nereden } \\
\text { Deryalar kirlendi gölü yozlaştı. }\end{array}$ & $\begin{array}{l}\text { We do not see the world through a narrow window } \\
\text { From whence did the owner, the king of this world come } \\
\text { The seas have been dirtied and the lake debased. }\end{array}$ \\
\hline $\begin{array}{l}\text { Seyfili gözlerim alınsın gala } \\
\text { Her şey tam bitmedi biraz var hala } \\
\begin{array}{l}\text { Zorla dayatırlar hep bile bile } \\
\text { Arının kovanda balı yozlaştı. }\end{array}\end{array}$ & $\begin{array}{l}\text { Seyfili let my eyes remain true } \\
\text { Not everything is quite gone, there is hope still } \\
\text { Though our hands are forced } \\
\text { And the honey in the beehive has degenerated. }\end{array}$ \\
\hline
\end{tabular}

\begin{tabular}{|l|l|}
\hline Ayıkmıyor Başım & $\underline{\text { I Can't Clear My Head }}$ \\
\hline $\begin{array}{l}\text { Ayıkmıyor başım kederden dertten } \\
\text { Figan ayrı düştü, zar ayrı düştü } \\
\text { Yolumu şaşırdım borandan, kıştan } \\
\text { Dolu ayrı vurdu kar ayrı düştü } \\
\text { Haydar Haydar Haydar kar ayrı düştü. }\end{array}$ & $\begin{array}{l}\text { I can't clear my head, from grief and from pain } \\
\text { The plaint and the die have fallen awry. } \\
\text { The hail and the snow have parted } \\
\text { Haydar, Haydar, Haydar, the snow has parted. }{ }^{32}\end{array}$ \\
\hline $\begin{array}{l}\text { Riza ile lokma yenilmez oldu } \\
\text { Kırkların cemine gidilmez oldu } \\
\text { Gülbenkler çekilip verilmez oldu } \\
\text { Talip ayrı düştü, pir ayrı düştü } \\
\text { Haydar Haydar Haydar pir ayrı düştü. }\end{array}$ & $\begin{array}{l}\text { The lokma could no longer be eaten with consent } \\
\text { The Cem of the Forty could not be held. } \\
\text { Prayers could not be read, could not be given } \\
\text { The disciple and the pir have parted }\end{array}$ \\
\hline $\begin{array}{l}\text { Seyfili bir sevda bu yoludar, Haydar, the pir has parted. } \\
\text { Demirden leblebi, ateşten gömlek } \\
\text { Özveri gerekir Nesimi olmak } \\
\text { Mansur ayrı düştü, dar ayrı düştü } \\
\text { Haydar Haydar Haydar dar ayrı düştü. }\end{array}$ & $\begin{array}{l}\text { Mansur and his hard times have parted. } \\
\text { Haydar, Haydar, Haydar the hard times have parted. }\end{array}$ \\
\hline
\end{tabular}




\section{NOTES}

1. The three major didactic poets are Shah Hata'i, Pir Sultan Abdal and Kul Himmet, although different Alevi traditions appear to emphasize different poets.

2. The author carried out fieldwork interviews with Ozan Seyfili at his home near Antalya between September 2009 and May 2010.

3. Not all Alevi aşılks are of dede lineage, and not all dedes sing and play the saz. If this is the case then an aşık (sometimes, 'zakir') will accompany him and provide musical direction in the cem.

4. Many Alevi communities suffered intense periodic persecution under the Ottoman Sultans (Imber 1979). They also suffered a number of violent massacres in the $20^{\text {th }}$ century, most significantly in the Dersim region in the 1930s and the towns of Kahramanmaraş, Çorum and Sivas in the 1970 s and 90 s.

5. These observations are made with an awareness that certain aspects of (historical) Alevilik are being emphasized more than others in the context of its contemporary reformulation and transformation.

6. English translations of the poems are by the author. The full texts of each poem cited in the article are given, with translation, in the Appendix below.

7. This concept is most clearly seen in the progression through the different stages of the Sufi path. (Ernst in Lewisohn 1999: 435-455).

8. Persian to English translation by the author, with acknowledgement to Dr. Leonard Lewisohn.

9. In this Sufi allegorical tale, thirty birds (individual souls) are guided by the hoopoe (the pir) towards the mystical Simurgh, who represents God. At the end of the journey, and by way of a clever linguistic pun, the thirty birds realize that the Simurgh (literally, 'thirty birds') is in fact no more than the sum of their own existence, an important point of Sufi doctrine - one with pantheistic implications - as regards the existence of God through creation rather than in transcendence over it.

10. Quoting the Divan of Rumi, $721 / 7577$.

11. Hafiz addresses his beloved directly with the words, 'To die by the stroke of your blade is life eternal.' (Ghazal CCCLV, line 11, in Avery and Heath-Stubbs 1952: 63) For more on kushta-yi ma'shuq, see the discussion in Seyed-Gohrab 2003: 129-136.

12. Quoted and translated from the Persian by Seyed-Gohrab.

13. The mum söndü allegation is that the Alevi cem ceremony - in which men and women participate together - culminates in the candles being extinguished, and in sexual orgy. Mum söndü is a historic accusation directed at Kızılbaş-Alevi as well as other 'heretical' minority groups. For an Alevi response to recent allegations, see Yaman 2007: 91-95.

14. The cem cannot commence until all members of the assembly have declared that they are at peace (riza) with one another and bear no grudges. If any are declared to exist, they must be resolved at this point by the presiding dede.

15. The correct spelling of the word for brother is with a ' $k$ ' and an ' $e$ ': kardeş. Seyfili's spelling and the pronunciation calls to mind the rural dialects of eastern Anatolia.

16. The semah is the rotational ritual dance with which the cem ceremony culminates. There is a particular semah that is named after the crane, the Turna Semahl.

17. Polygamy was outlawed by the Turkish Republic but remains permissible under the Islamic shari'a, which is the point of comparison often made by the Alevis. 
18. It is often found in partnership with the image of the moth (the mystical soul) that is irresistibly drawn to the flame (God) but will inevitably immolate itself in its heat when it achieves the desired union.

19. Cahit Öztelli reports that Turabi was the dedebaba (head of the Bektaşi Sufi order) at the convent in Hacıbektaş in 1849, and that he died in 1868. He considers him a valuable Bektaşi poet (Öztelli 1973: 371). For Turabi's collection of poetry, see Turabi (Ali Dedebaba) Divan 1294 AH.

20. Edip Harabi is the author of the Vahdetname, a long poem outlining Alevi creation mythology.

21. Ebu Turab (Father of the Earth) is also one of the titles given to Ali in Alevilik.

22. For more on innovation and originality in Turkish folk music, see Markoff 1991:129-145, especially pp.136-7.

23. In Alevi society, each male individual or married couple is joined to another by way of a ritual pledge of lifelong attachment, known as musahiplik. The bond between two musahips is considered to be closer than that of blood brothers.

24. Altan Gökalp suggests that mysticism served as both religious legitimization and a form of social control in small-scale rural Alevi communities (Gökalp 1980: 175-178).

25. Millet means nation; in Ottoman usage it referred to the religious groups (broadly: Muslim; Jewish; Greek Orthodox; Armenian; Assyrian) according to which the Empire was organised.

26. 'Hü' does not have an easy translation. It is the Arabic term for 'he' (ie, God). The word is used in the course of the cem - at the instigation of the dede, although it is repeated by the assembly with an imperative sense of sitting up and paying attention.

27. The sacred people, ie the Alevis.

28. Lit. 'narrow', denoting the place of ritual examination during particular cem ceremonies.

29. The correct spelling is kardeș. Seyfili's use of the ' $G$ ' and the 'a' here are evocative of the eastern Anatolian rural dialect.

30. Pertaining to dust.

31. Ruin, or poverty.

32. Haydar is a name used by the Alevis for Ali.

\section{ABSTRACTS}

The Alevi tradition in Turkey is characterized by a profoundly mystical religious worldview. Its poetic culture, aşıklk, is heavily influenced by the language and mystical motifs of Persian Sufism. Yet whilst the major precepts of Sufi theology and ritual practice undeniably constitute an important influence on Alevilik, there are areas of its mysticism that are uniquely Alevi. This paper explores the particularities of Alevi mysticism by analyzing the context and meaning of the Sufi poetic idiom in Alevi poetry. The subject is approached through an ethnographic study of the life and poetry of a contemporary Alevi aşı from Erzincan, called Ozan Seyfili, the span of whose life covers the past six decades. It concludes by considering the future prospects for Alevi mysticism as the community codifies and reformulates its traditions in the present day.

\section{INDEX}

Keywords: Alevi, mysticism, aşık poetry, community, migration, persecution 
AUTHOR

\section{CAROLINE TEE}

Postdoctoral Research Fellow, Department of Archaeology and Anthropology, University of Bristol 